\title{
DECREASE IN SPECIFIC ACTIVITY OF HEART AND MUSCLE ALDOLASE IN OLD MICE*
}

\author{
C. J. Chetsanga AND M. LiskiWsky \\ Biochemistry Program, Department of Natural Sciences, University of Michigan, Dearborn, MI 48128, U.S.A.
}

(Received 21 April 1977)

\begin{abstract}
Aldolase was purified from mouse heart and muscle cells by column chromatography. The enzyme from 3- and 30-month old mouse tissues was assayed under different temperature and $\mathrm{pH}$ conditions in order to determine the effect of these parameters on the activity of aldolase from the two age groups.

2. The results showed that the specific activity of aldolase decreases as a function of mouse senescence. The specific activity of young mouse muscle aldolase is $1 \frac{1}{2}$ times that of the enzyme from old mouse muscle. This trend was also observed with heart cell aldolase.

3. These results indicate that the heart and muscle cells of old mice accumulate inactive molecules of aldolase.
\end{abstract}

\section{INTRODUCTION}

One of the most basic metabolic processes in cells is the breakdown of glucose to release energy. The metabolic events involved in glycolysis also provide a means by which carbon atoms become available to cells. The first step in hexose breakdown is the cleavage of fructose 1,6-diphosphate (FDP) into dihydroxyacetone phosphate and glyceraldehyde 3-phosphate catalyzed by aldolase (E.C. 4.1.2.7.). An interesting problem to investigate is how the catalytic properties of aldolase are affected by different metabolic conditions including senescence.

Studies from this laboratory have shown that old mouse DNA accumulates single-stranded gaps (Chetsanga et al., 1975, 1977). In the present study, experiments were carried out in order to determine if these structural changes in the DNA of senescent mice could in some way be correlated to some changes in the properties of aldolase. The specific activity of aldolase has been shown to decrease with age in nematodes (Zeelon et al., 1973), mouse liver (Gershon \& Gershon, 1973), and rabbit liver (Anderson, 1974). In rat liver on the other hand, the specific activity of aldolase does not change with age (Anderson, 1976).

Since the decrease in aldolase activity is not common to all rodents, it would be interesting to determine whether aldolase shows an age-associated decline in activity in mouse tissues other than liver. There is precedence for an enzyme showing different age-associated properties in different organs of the same organism; catalase level increases with age in rat liver but decreases in the kidneys of old rats (Leutert et al., 1975).

We measured the activity of mouse heart and muscle aldolase under conditions of different temperature and $\mathrm{pH}$ in order to determine the effect of these factors on the catalytic properties of the enzyme. The results show that the specific activity of aldolase decreases in heart and muscle cells of old mice.

*This investigation was supported by grant No. 340879 from the Michigan Heart Association.

\section{MATERIALS AND METHODS}

The CBF, male mice used in this investigation were obtained from Charles River Breeding Laboratories. They were fed on antibiotic-free Agway diet specially formulated for Charles River Breeding Laboratories and maintained at three animals per cage. Food and bedding were well sterilized. These mice have a mean life-span of $30 \pm 2$ months.

\section{Aldolase preparation}

Mouse heart and muscle aldolase was prepared by the method of Penhoet et al. (1969) with slight modifications. The tissues were obtained from 3- and 30-month old mice, killed by cervical dislocation. The tissues were minced with a pair of scissors and rinsed with several changes of a chilled solution of MET ( $3 \mathrm{mM}$ 2-mercaptoethanol, $2 \mathrm{mM}$ EDTA, $25 \mathrm{mM}$ Tris-HCl, pH 7.5). Subsequent steps were carried out at $0-4^{\circ} \mathrm{C}$. The minced tissues were homogenized in two volumes of MET with ten passes of the pestle and filtered through four layers of cheesecloth.

After centrifuging at $12,000 \mathrm{~g}$ for $30 \mathrm{~min}$, the supernatant was decanted and made $45 \%$ in ammonium sulfate. The suspension was stirred $45 \mathrm{~min}$ and centrifuged for $1 \mathrm{hr}$ at $14,000 \mathrm{~g}$. The supernatant was collected and made $60 \%$ in ammonium sulfate. After allowing to stand for $90 \mathrm{~min}$, the suspension was centrifuged at $14,000 \mathrm{~g}$ for $1 \mathrm{hr}$ and the pellet dissolved in $1 \mathrm{mM}$ EDTA, $10 \mathrm{mM}$ Tris-HCl, $\mathrm{pH}$ 7.5. The extract was desalted by filtering through a Sephadex G-25 column.

The desalted enzyme preparation was loaded on a phosphocellulose column $(2 \times 50 \mathrm{~cm})$. The column was washed Ah two column volumes of $1 \mathrm{mM}$ EDTA, $10 \mathrm{mM}$ Tris- $\mathrm{HCl}, \mathrm{pH} 7.5$, and the enzyme eluted with a linear gradient of $0-0.1 \mathrm{M} \mathrm{NaCl}$ in $1 \mathrm{mM}$ fructose diphosphate, $5 \mathrm{mM}$ EDTA, $50 \mathrm{mM}$ Tris- $\mathrm{HCl}$, pH 7.5. The fractions with peak enzyme activity were pooled and used in the experiments described below.

\section{Enzyme assay}

The $1.0-\mathrm{ml}$ reaction mixture consisted of $1.2 \mu$ mole of FDP, $0.3 \mu$ mole of NADH, $10 \mu \mathrm{g}$ of $\alpha$-glycerophosphate dehydrogenase/triose phosphate isomerase, $100 \mu$ moles of glycylglycine buffer, pH 7.5, and $0.1 \mathrm{ml}$ of aldolase. Assays were carried out, at $25^{\circ} \mathrm{C}$ using a Beckman recording spcctrophotometer, essentially by the method of Blostein and Rutter (1963). A unit of aldolase is defined as the amount of enzyme catalyzing the cleavage of $1 \mu$ mole of FDP per 
min at $25^{\circ} \mathrm{C}$ under these assay conditions. The specific activity of aldolase was computed as units per milligram of protein.

Protein concentration was measured by the method of Lowry et al. (1951) with bovine serum albumin (Sigma) as a standard.

\section{RESULTS}

The results presented in this paper were obtained in four separate experiments in which heart and muscle tissues from 3-month and 30-month old mice were used. Figure 1 shows the chromatographic profiles obtained when aldolase was resolved on a Sephadex G-25 and a phosphocellulose column. In some experiments, we observed a reduction in aldolase activity after the fractionation on the phosphocellulose column. The enzyme elutes in fractions 6-11 of the phosphocellulose column (Fig. 1B). With some enzyme preparations there was some loss in enzyme activity following phosphocellulose chromatography.

To simplify presentation we are showing only the data obtained with muscle aldolase. The results obtained with heart aldolase were comparable except that the specific activity of heart aldolase was slightly lower than that of muscle aldolase for any given age group.

When the catalytic properties of heart and muscle aldolase from 3- and 30-month old mice were compared, the aldolase from old mouse muscle cells had a lower specific activity than that of young mouse aldolase (Fig. 2). The specific activities of the enzymes from the two age groups are closer in the region of lower substrate concentration, but do diverge sub-

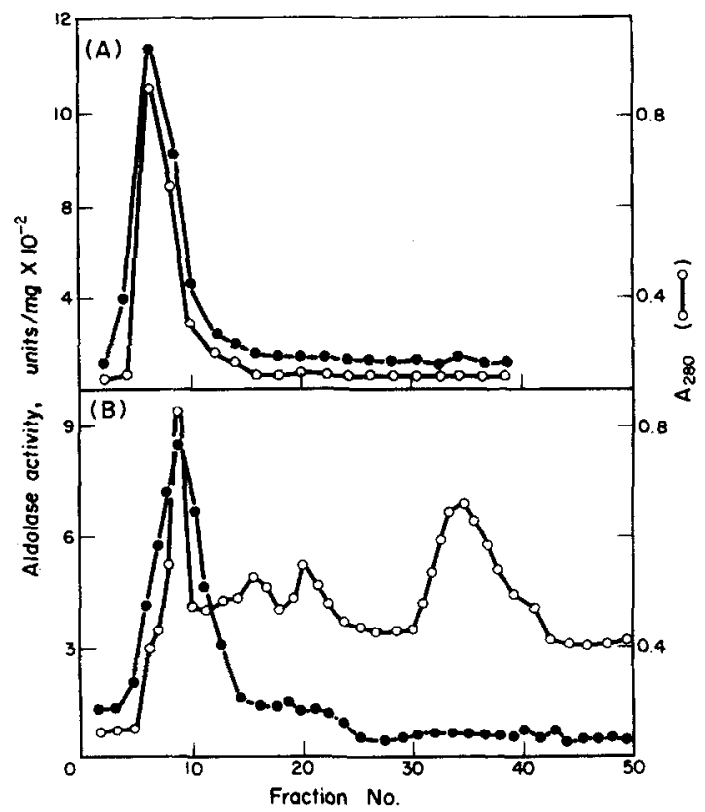

Fig. 1. Chromatography of aldolase on Sephadex G-25 and phosphocellulose columns. (A) The enzyme recovered after ammonium sulfate precipitation was passed through a column of Sephadex G-25; this purification step desalted the protein. $\mathbf{A}_{280}, 0$; aldolase activity, - . (B) The enzyme was loaded on a phosphocellulose column and eluted with a linear gradient of $0-0.1 \mathrm{M} \mathrm{NaCl}$ in $1 \mathrm{mM} F D P$, $5 \mathrm{mM}$ EDTA, $50 \mathrm{mM}$ Tris- $\mathrm{HCl}, \mathrm{pH} 7.5 \mathrm{~A}_{280}$, O; aldolase activity,

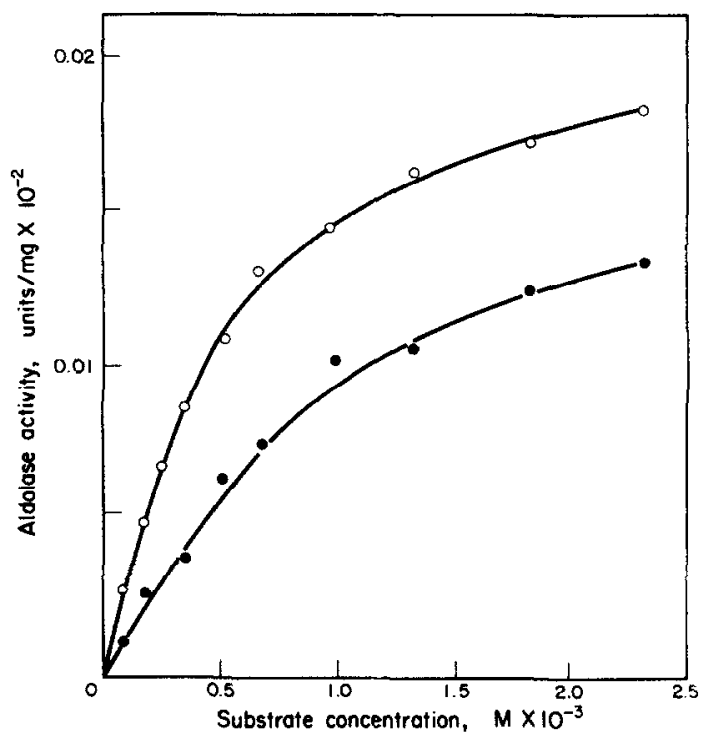

Fig. 2. Effect of substrate concentration on aldolase activity. The catalytic action of aldolase from mice of two age groups was measured using increasing concentrations of fructose diphosphate. Activity of aldolase from 3-month (O), and 30-month (e) old mice.

stantially in the region of higher substrate concentration. The observed comparability of the levels of specific activities in the region of lower substrate concentration is probably due to excess amounts of enzyme. The reaction catalyzed by heart aldolase showed a similar trend (data not shown).

Table 1 presents a summary of the specific activity and the Michaclis constants of young and old mouse heart and muscle aldolase. Old muscle aldolase had a $K_{m}$ of $4.9 \times 10^{-6} \mathrm{M}$; the aldolase from young mouse muscle had a $K_{m}$ of $4.4 \times 10^{-6} \mathrm{M}$. Aldolase from old heart cells had a $K_{m}$ of $5.4 \times 10^{-6} \mathrm{M}$ and that from young heart cells had a $K_{m}$ of $4.8 \times 10^{-6} \mathrm{M}$. These results are comparable to those obtained by Gershon and Gershon (1973) with the liver aldolase of aging mice.

Figure 3 shows the level of aldolase activity at different $\mathrm{pH}$ values. The broadness of the $\mathrm{pH}$ optimum region of the enzyme is readily apparent. This $\mathrm{pH}$ optimum covers the range of 5-8. It can be observed that the aldolase from young mouse muscle has a higher specific activity at the different $\mathrm{pH}$ values utilized. Both young and old mouse aldolase activities decrease at $\mathrm{pH} 9.0$.

The assay system we used is based on the oxidation of NADH in a reaction that is coupled to the cleavage of FDP. The oxidation can be monitored by following the decrease in the absorbance of NADH at $340 \mathrm{~nm}$. The apparent decline in the change in $A_{\mathbf{3 4 0}}$ under the alkaline conditions may be due in part to a very rapid chemical dissociation of $\mathrm{H}^{+}$from NADH.

It is possible that old muscle aldolase undergoes some structural modifications that adversely affect the enzyme's catalytic properties (Anderson, 1976). Such changes are likely to render the enzyme more labile and temperature sensitive. To test this hypothesis we measured the activity of aldolase at different temperatures. Our results show that young and old mouse aldolase activity increases until $40^{\circ} \mathrm{C}$; a further rise 
Table 1. Comparison of catalytic properties of heart and muscle aldolase from young and old mice ${ }^{a}$

\begin{tabular}{lcc}
\hline & \multicolumn{2}{c}{ Ages of mice } \\
& 3 months & 30 months \\
\hline (a) Muscle aldolase: & & \\
Specific activity (units/mg) & $0.049 \pm 0.004$ & $0.032 \pm 0.005$ \\
$K_{m}$ (FDP) $\left(\times 10^{-6}\right)$ & $4.4 \pm 0.051$ & $4.9 \pm 0.48$ \\
(b) Heart aldolase: & $0.044 \pm 0.005$ & $0.028 \pm 0.004$ \\
Specific activity (units/mg) & $4.8 \pm 0.32$ & $5.4 \pm 0.4$ \\
$K_{m}$ (FDP) $\left(\times 10^{-6}\right)$ & \\
\hline
\end{tabular}

${ }^{a}$ The results are based on averaged data from four separate experiments. The ranges are indicated in parentheses.

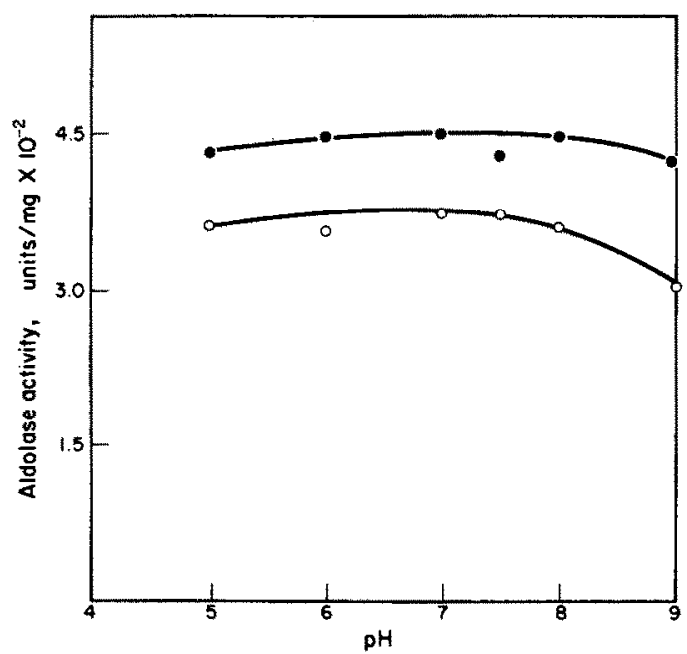

Fig. 3. Effect of pH on aldolase activity. 3 and 30 month muscle aldolase was assayed under conditions of varying pH. 3 Month (O), and 30 month (O) aldolase activity.

in temperature led to a decline in enzyme activity (Fig. 4). There is no indication that the enzyme from old mice was more temperature sensitive than that from young mice.

\section{DISCUSSION}

The results obtained in the present investigation support those of Gershon and Gershon (1973) who

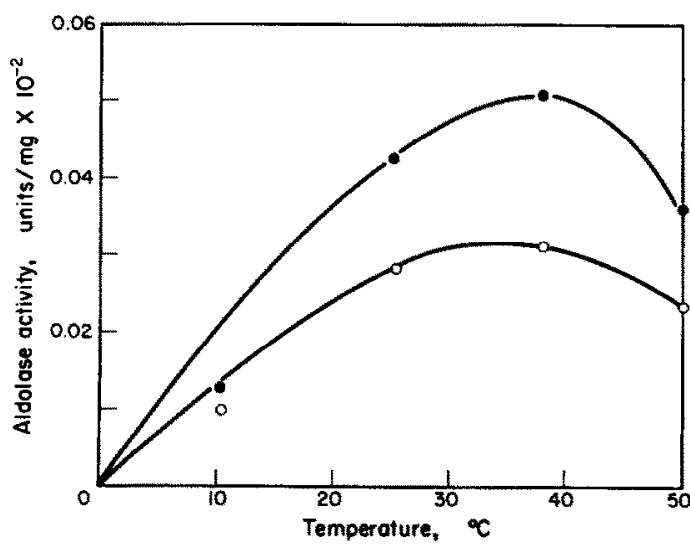

Fig. 4. Effect of temperature on muscle aldolase activity. The activity of 3 and 30 month muscle aldolase was measured at $0-50^{\circ} \mathrm{C}, 3 \mathrm{Month}(\odot)$, and 30 month $(0)$ aldolase activity. reported a decrease in the specific activity of aldolase in old mouse liver. Our studies show that this decline in aldolase activity occurs in both heart and muscle cells of old mice.

The age-associated decline in the specific activity of aldolase results in a slightly higher $\boldsymbol{K}_{m}$ for the old mouse enzyme than for young mouse aldolase. Such a trend has also been obtained with aldolase from other sources (Gershon \& Gershon, 1973; Anderson, 1974). This phenomenon is not unique to aldolase as nematode isocitrate lyase (E.C. 4.1.3.1) (Gershon \& Gershon, 1970), human glucose-6-phosphate dehydrogenase (E.C. 1.1.1.49) (Holliday \& Tarrant, 1972) and human lactate dehydrogenase (E.C. 1.1.1.27) (Lewis \& Tarrant, 1972) have also been observed to be similarly affected by old age.

The decrease in the catalytic properties of aldolase as a function of mouse age suggests that the enzyme may undergo structural modification(s) in old mouse tissues. When aldolase was assayed under different $\mathrm{pH}$ conditions, the old mouse enzyme continued to show a lower level of activity at all $\mathrm{pH}$ values utilized. The rationale for this experiment was to determine if the $\mathrm{R}$ groups of some amino acids in old mouse aldolase become altered with age. Modification of $\mathbf{R}$ groups of amino acids in proteins is not without precedence. Esmon et al. (1975) have reported that the synthesis of prothrombin from its precursor, involves a vitamin $\mathrm{K}$-dependent carboxylation of the $\gamma$-carbon of the glutamic acid residue at the amino terminal to form $\gamma$-carboxyglutamic acid residues. This step representing a post-translation modification of the prothrombin precursor paves the way for the formation of thrombin which is active in blood clotting.

In the case of aldolase, our model predicts a modification that would lead to a reduction in its activity. By progressively raising the $\mathrm{pH}$, the expectation was that a $\mathrm{pH}$ value that affects young and old mouse aldolase differently, would be identified. Such a pH would presumably make the modified old mouse aldolase assume a conformation or ionic form that interferes with its catalytic activity. Our results showed that young and old mouse aldolase behaved identically under all the $\mathrm{pH}$ conditions tested; the activity of aldolase from both age groups decreased at $\mathrm{pH} 9.0$. This alkaline $\mathrm{pH}$ may have adversely affected the catalytic constituents of aldolase.

The possibility that aldolase undergoes structural alterations in old mouse heart and muscle cells was further examined by assaying its activity at different temperatures. Raising the temperature of a reaction 
is known to provide a greater amount of kinetic energy which will in turn increase the velocity of the reaction. The rising temperature finally reaches a level at which the expected increase in the velocity of the reaction now becomes offset by an increasing rate of enzyme denaturation (Segel, 1975).

It was our expectation that any modification in old mouse aldolase would make the enzyme exhibit a temperature sensitivity different from that of young mouse aldolase. Studies with other systems have shown that some enzyme activities in aging cultured cells become more heat labile (Holliday \& Tarrant, 1972; Goldstein et al., 1975). Our results showed that the aldolase from the tissues of both young and old mice have similar temperature sensitivity.

The molecular mechanisms underlying the decline in aldolase activity remain enigmatic. Alterations in genome structure are likely to result in the production of aberrant proteins (Chetsanga et al., 1977). Altered proteins could also arise from random errors in protein synthesis (Orgel, 1973), post-translational modification (Sadowski et al., 1976), or some failure in the degradative process (Goldberg \& St. John, 1976). Aldolases from young and old mouse livers have been shown to be antigenically identical and to have similar electrophoretic mobility (Gershon \& Gershon, 1973). In the light of the available data, modifications in aldolase structure are likely to be of a subtle nature.

\section{CONCLUSION}

Our results demonstrate that the specific activity of heart and muscle aldolase decline as the mouse ages. These differences in specific activity of the enzyme persisted under different $\mathrm{pH}$ and temperature conditions. The basis for the decrease in enzyme activity still needs to be resolved. It seems that old mouse aldolase undergoes subtle structural alterations which lead to a decline in its catalytic activity.

\section{REFERENCES}

ANDERson P. J. (1974) Aging effects on the liver aldolase of rabbits. Biachem. J. 140, 341-343.

ANDERSON P. J. (1976) The specific activity of aldolase in the livers of old and young rats. Can. J. Biochem. 54, $194-196$.

Blostein R. \& Rutrer W. J. (1963) Comparative studies of liver and muscle aldolase-II. Immunochemical and chromatographic differentiation. $J$. biol. Chem. 238, $3280-3289$.

Chetsanga C. J., Boyd V., Peterson L. \& Rushlow K. (1975) Single-stranded regions in DNA of old mice. Nature, New Biol. 253, 130-131.

Chetsanga C. J., Tutrue M., JaCoBoni A. \& Johnson C. (1977) Age-associated structural alterations in senescent mouse brain DNA. Biochim. biophys. Acta 474, 180-187.

Esmon C. T., Grani G. A. \& Sumte J. W. (1975) Purification of an apparent rat liver prothrombin precursor: characterization and comparison to normal rat prothrombin. Biochemistry 14, 1595-1600.

GershoN H. \& GeRShON D. (1973) Inactive enzymes in aging mice: liver aldolase. Proc. natn. Acad. Sci., U.S.A. 70, 909-913.

Goldberg A. L. \& ST. JOHN A. C. (1976) Intracellular protein degradation in mammalian and bacterial cells-II. A. Rev. Biochem. 45, 747-803.

Goldostein S, Niewiarowski S. \& Singal D. P. (1975) Pathological implications of cell aging in vitro. Fedn Proc. Fedn Am. Socs exp. Biol. 34, 56-63.

Holl.tDay R. (1975) Growth and death of diploid and transformed human fibroblasts. Fedn Proc. Fedn Am. Socs exp. Biol. 34, 51-55.

Holliday R. \& Tarrant G. M. (1972) Altered enzymes in aging human fibroblasts. Nature, New Biol. 238, $26-30$.

Leutert $G$, Rotzsch W. \& Beier W. (1975) On the aging of the intermitotic cells-investigations on enterocytes and hepatocytes. In Cell Impairment in Aging and Development: Advances in Experimental Medicine and Biology, (Edited by Cristofalo V. J. \& Holeckova E.) Vol. 53, pp. 235-245. Plenum Press, New York.

Lewis C. M. \& TARRANT G. M. (1972) Error theory and aging in human diploid fibroblasts. Nature, New Biol. $239,316-318$.

Lowry O. H., Rosebrough N. J., FARR A. L. \& RANDall R. J. (1951) Protein measurement with the Folin phenol reagent. J. biol. Chem. 193, 265-275.

ORGEL L. E. (1973) Aging of clones of mammalian cells. Nature, New Biol. 243, 441-445.

Penhoet E. E., Kochman M. \& Rutrer W. I. (1969) Isolation of fructose diphosphate aldolases A, B, and C. Biochemistry 8, 4391-4395.

SADOWsk. J., Esmon C. T. \& Sutrie J. W. (1976) Vitamin $\mathrm{K}$-dependent carboxylase. Requirements of the rat liver microsomal enzyme system. $J$. biol. Chem. 251 , $2770-2776$.

SEGEL I. H. (1975) Enzyme Kinetics, pp. 926-942. John Wiley, New York.

ZeElon P., Gershon H. \& Gershon D. (1973) Inactive enzyme molecules in aging organisms. Nematode fructose 1,6-diphosphate aldolase. Biochemistry 12, 1743-1750. 